\title{
The Accounting Practice of Small and Medium Sized Enterprises and Its Effect on Access to Finance: A Case Study of Arba Minch Town, Southern Region, Ethiopia
}

\author{
Negalign Nigatu Oynaka \\ MSC in Accounting and Finance, Lecturer in Wolaita Sodo University
}

\begin{abstract}
In developing countries, small and medium enterprises (SMEs) have a vibrant role and serve as engines through which the growth objectives of developing countries can be achieved. The SME sector has been instrumental in bringing about economic transition by providing goods and services, which are of adequate quality and are reasonably priced, to a large number of people, and by effectively using the skills and talents of a large number of people without requiring high level training, large sums of capital or complicated technology. However access to finance remains to be a major problem hampering SMEs from playing their productive role in the economy. Accounting is also basically defined as the process of recording economic information in a significant manner in order to measure the performance of a firm. Accounting practices consist of the methods and records established by management to identify, assemble, analyze, classify, record and report a company's transactions and to provide assurance that the objectives of internal control are being met. In Ethiopia one of the main problems of SMEs' may be their access to finance and not practicing formal accounting system. This study was conducted to examine the accounting practice of small and medium sized enterprises and its effect on access to finance in the case of Arba Minch town. For this study different literatures were reviewed and both primary and secondary data were collected from different sources. For the achievement of the objective of the study both research approach particularly survey design was used and the data analyzed using descriptive statistics and multiple regression models. The government in collaboration with financial institutions should therefore work to solve this problem.

Keywords: Access to finance, Age of the business, Accounting practice, Collateral
\end{abstract}

DOI: $10.7176 / \mathrm{EJBM} / 11-28-04$

Publication date:October $31^{\text {st }} 2019$

\subsection{Background of the Study}

Small and medium sized enterprises are an important ingrate for stable and equitable growth in any national economy. Ethiopia takes the development and expansion of SME's as the main way to solve many of the social problems. A universal definition of micro and small enterprise does not exist given the multitude of different economic, social and geographic differences with the international context of micro and small enterprise. In some countries, micro and small enterprises are categorized based on the capital that is invested and in some countries based on the employment opportunity they provide.

SMEs were classified into four main categories; Journal of Finance and Accounting 2014 Micro enterprises are those that employ less than 6 people; Very small enterprises constitute those employing 6-9 workers; Small enterprises are business units that employ between 10 and 29 people. This study therefore defines SMEs as enterprises that employ not more than 30 people. Accounting Practices and Book-Keeping in SMEs It is reiterated that accounting is paramount in any business. Accounting is basically defined as the process of recording economic information in a significant manner in order to measure the performance of a firm. Basic accounting is needed to "keep the score" so that the entrepreneur knows what is happening in the business, how much has been sold, what the costs are, what activities are profitable, whether selling prices leave a suitable margin against cost and so on.

Accounting practices consist of the methods and records established by management to identify, assemble, analyze, classify, record and report a company's transactions and to provide assurance that the objectives of internal control are being met. This is sometimes called the accounting system. It analyze, record and measures business transactions to ascertain the performance of an entity. Efficient financial mangers reside on the past and present in order to predict the future and for proper evaluation and comparison of financial activities.

UNCTAD (2000), observed the need for promoting transparency with adequate records-keeping early on in the business development phase of SMEs as paramount. Some form of recording will be essential to all business for the day-to-day management of their operations and the fulfillment of unavoidable governmental obligations (e.g. taxation). It is well known that inadequate record keeping is frequently associated with failures in small businesses even if it is not actually the direct cause of failure. For record keeping purposes the enterprise can use different methods. A report submitted by the European Commission Enterprise and Industry Directorate-General on the accounting systems for small enterprises (2008), suggested the following as the main books to be kept by an SME owner: Purchase day book, Sales day book, Cash book, Petty cash book, Expenditure book, Payroll records, Assets register etc. 
Accounting Controls in SMEs With regards to accounting controls; defines accounting controls as the measures that relate to protection of assets and to the reliability of accounting and financial reports. Regarding accounting control procedures for small and micro business enterprises, observed that it is important to have a system of control over all business activities, as a well-designed and properly implemented control system can ensure: protection of resources against waste and fraud; accuracy and reliability in accounting data; and success in the evaluation of the performance of the business.

Academicians and development economists have supported the promotion of micro and small business enterprise towards job creation, poverty reduction, innovation etc. With the increasing unemployment and poverty, micro and small enterprises come to the front in employment creation and income generation. The SME sector is believed to be able to fill the gap that exists between the poor and the rich in developing countries regarding income generation and, unemployment rate.

Successful small businesses are the primary engines for economic development such as income growth and poverty reduction in many of the developing countries. These businesses can also build foundation for stable communities and gender equality. However, poor infrastructure, weak public service, inadequate mechanisms for dispute resolution and lack of markets to their product and formal financing remain major impediments to small business growth (MELFED 2004).

Small and medium enterprises (SMEs) have been recognized as a major source of employment and income in many countries of the Third World (Mead \&Liedholm, 1998). It is obvious that finance plays a key role in any aspect of business operation. Finance issued to start up, expand, diversify and for working capital of the businesses firms. Without finance, no one-business enterprise can achieve its objectives. As far as SMEs are concerned as part of business enterprises, they also need finance. Mckernan and Chen (2005) stated that finance is the backbone of any business enterprise, including SMEs.

SMEs need finance from start up to finance of its growth, expansion, diversification and smooth operation at any time in its life cycle. Small and medium sized enterprises are an important ingredient for stable and equitable growth in any national economy. Ethiopia takes the development and expansion of SME's as the main way to solve many of the social problems.

However, the sector is facing financial challenges, which impeded its role in the economy. These challenges are lack of access to credit, insufficient loan size, time delay and collateral (Gebrehiwot and wolday, 2004). According to Molhotraet al. (2006), MSEs play a pivotal role in developmental goals such as in improving living standard, distributing income fairly among low level and high level group, reducing unemployment rate, fostering linkages among various economic sectors, easy to begin and expand, labor intensive, require small capital, low technology, and little know how, this sector is receiving due attention of policy makers and development practitioners. Furthermore, SMEs serve as a bridge to reach at the technically advanced medium and large enterprises.

In Ethiopia one of the main problems of SME's may be their access to finance and not practicing formal accounting system and has no well-developed access to finance. Limited usage of financial and management accounting reports could be attributed to SMEs' inability to employ professional managers with functional specialization especially in the financial area due to their limited financial resources. Without adequate, effective and timely financial reports and analysis, the SMEs are losing out on the benefits from those practices such as improved monitoring of financial progress, improved ability to anticipate fortunes or failures, better assessments of financial risks and greater ease in financial planning and control. The main aim of this study was to examine the accounting practice of SME's and its effect on access to finance a case of Arba Minch town southern region of Ethiopia.

\subsection{Statement of the Problem}

In almost all economies of the world, small and medium enterprises are vital for sustained growth. SMEs are generally regarded as the driving force of economic growth job creation and poverty reduction in developing countries.

In Ethiopian context, as to the Ethiopian government's strategy, Growth and Transformation plan, small and medium enterprises are the bridge to achieve the goals of the government (MoFED, 2011). Since Ethiopia is a developing country, policy makers of the country pay due attention for SME sectors. Due to their low capital requirement, easy of startup and operate, easy to operate in urban and semi urban areas or environments with small expenditure, they attract the attention of the government.

Poor record keeping and inefficient use of accounting information are a major cause of the above according to Berryman (Berryman1982 quoted in Siop 1997, Walton 2000, Wichmann 1983, World Bank 1978). The inefficient use of the accounting information to support their financial decision-making and the low quality and reliability of financial data are part of the main problems of SMEs (Ubonratchathanee University 2000).

SMEs lack of access to capital and high interest rates charges are partially the result of incomplete (or no) accounting records, and the inefficient use of accounting information. Poor record keeping and accounting 
information make it difficult for financial institutions to evaluate potential risks and returns, making them unwilling to lend to SMEs (World Bank 1978). As a result, SMEs pay high interest rates or fall back on the middlemen or moneylenders, whose loans are costly and often restrictive (Institute for Small and Medium Enterprises Development). The misuse and inaccuracy of accounting information causes SMEs to inaccurately assess their financial situation, and make poor financial decisions, as well as leads them to face with the high failure rate (Byron 1976).

Considering the enormous potentials of the SMEs sector, and despite the acknowledgement of its immense contribution to sustainable economic development, its performance still falls below expectation in many developing countries. SMEs frequently lack access to institutional credit, causing them to encounter high financing costs and high failure rates. The inefficient use of the accounting information to support their financial decisionmaking and the low quality and reliability of financial data are part of the main problems of SMEs. Accounting information is used to assess the profitability of alternative courses of action, measure performance, and evaluate the position of enterprises in term of profitability, liquidity, activity and leverage. It can be used to improve SME performance, especially financial decisions. Different capital structures cause different degrees of financial risk. These problems evidence the need to undertake extensive research on the accounting of SME's and its effect on access to finance. Therefore, this study may attempts to provide answers for the following basic research questions;

1. What kind of accounting /record keeping do SME practice in their business?

2. What times do you get access to credit the SMEs?

3. What are major source of credit available to SMEs and the types of finance used?

\subsection{Research Objective}

The general objective of this study is to identify the accounting practice and its effect on access to finance of SME's in Arba Minch Town, Southern Region Ethiopia.

Based on the above stated general objective the following specific objectives are drawn:

1. To determine Whether SME does maintain formal accounting practice or not.

2. To identify the access and major source of credit available to SMEs

3. To examine the types of finance used by SMEs.

\subsection{Review of related literature}

\subsubsection{Theoretical and conceptual literature review}

\subsubsection{Definition of Small and Medium Enterprise (SMEs)}

World Bank group (2004) stated that there are two met holds to define SMEs; namely size criteria and economic control. In relation to size criteria, World Bank group (2004) pointed out that different countries used various criteria such as number of employees, sales volume, asset size, insurance and volume of deposit to define SMEs. However, many countries commonly used the number of employees as the dominating criteria to define SMEs. Japan, Canada, and USA are good examples in point. Levitsky 12 (1988) strengthened the suggestions of Hailay and World Bank. For better classification, the World Bank group (2004) tabulated their definition as follows. With regard to economic control, Hailay (2003) stated that a given business can be enterprise.

There is no universally accepted single definition of micro and small enterprises. Hailay (2003) defined small enterprises in Ethiopia, having a capital investment from 20,000 birr to 50,000 birr, while micro enterprises are having less than 20,000 capital investment. This definition is in case of Ethiopia but there are many other countries that use number of employees to define micro and small enterprises. Malhotraet al (2006) defines SMEs as business institutions, which run their business activities under the supervision of their owners. The authors also specifically defined SMEs as entities that focus on micro-enterprise and are typically informal have less than 10 employees. A clear definition may be useful in a particular national context but it may not be practical to attempt a universal definition. An attempt is made to present some definitions of SMEs to demonstrate the divergence in definition across countries.

\subsubsection{Empirical Evidence}

Romney (2003) defined record keeping systems as set of components that collects, records, classifies, analyses, and processes and summarizes business transactions in the books of accounts. A system should be simple to use, easy to understand, reliable, accurate consistent and designed to provide information on a timely basis. According to Parker (2002) record keeping involves identification, classification, storage and protection, receipt and transmission, retention and disposal of records for preparation of financial statements. He also adds that record keeping also includes policies, systems, procedures, operations and personnel required to administer records. Mc Lean (1999) points out that good record management helps in controlling the creation and growth of records to reduce operating costs, assimilation of new records management technologies and in ensuring regulatory compliance. Poor record keeping, inefficient use of accounting information to support financial decision making and low quality and reliability of financial data are part of the main problems in financial management concerns 
of SMEs (Karunananda and Jayamaha ,2011).

There are two sources of finance available to SME which includes; internal and external sources (Chizea, 2002). Internal sources as the dominant source of finance for most small-scale businesses. A survey conducted by the World Bank (1995) on business environment in transitional economies showed that the share of internal funding is significantly lower in advanced reforming countries as follows: Estonia 33 percent, Poland 34 percent and Lithuania 37 percent. In the United States of America, the SMEs of less than two years old, internal finance constitute 54 percent of total financing. And for most businesses, internal sources of finance constitute retained earnings for the period including provisions made for depreciation which is essentially a book transfer.

The external sources of financing constitute bank finance and other forms of institutional credit. In India, the sources of external finance include informal channels, credit unions, and commercial banks which play an equally important role in the provision of external finance asserted by (World Bank 1995). These sources are certainly not dissimilar to the complement of sources of external finance available to most businesses in Ethiopia. External source of finance must also include public equity. The financial sector has changed significantly during recent decades. Higher competitive pressure and a greater concentration of banks have diverse impacts on lending practices.

Access to business information services has been identified as one area that needs attention from governments and business services providers if the SMEs sector in developing countries is to achieve sustainable levels of growth and development. Many firms in Africa operate in an information- poor environment due to lack of adequate business support services and the poor information technological infrastructures (Oshikoya\&Hussain, 2007). Access to information has however not been given the same attention as other constraints to growth of SMEs like access to finance, markets, technology or training.

Lack of access to credit/ finance is almost universally indicated as a key problem for SMEs. Credit constraints operate in variety of ways in Ethiopia where undeveloped capital market forces entrepreneurs to rely on selffinancing or borrowing from friends or relatives who are not enough to enable SMEs undertake their business activities optimally. Lack of access to long-term credit for small enterprises forces them to rely on high cost short term finance. There are various financial challenges that face small enterprises. They include the high cost of credit, high bank charges and fees. Numerous money lenders in the name of Pyramid schemes came up, promising hope among the 'little investors,' which they can make it to the financial freedom through soft borrowing.

In today's business world where consumer's credit and other types of credits being offered by banking sectors in developed and developing countries, it is amusing to see the small scale business, change agent, suffer from luck of access to finance in these country. As known an important role of banks is to provide relationship lending services that help resolve problems in providing external finance to informational obscure small businesses (Berger and Udell, 1994).

The rationale behind turning to these schemes among a good number of entrepreneurs is mainly to seek alternatives and soft credit with low interest rates while making profits. Financial constraint remains a major challenge facing SMEs in Kenya (Wanjohi and Mugure, 2008). Finding start-up finance for the business is the biggest hurdle that many entrepreneurs go through. Even after getting started, getting sufficient finance to sustain business growth is another problem.

In Ghana SMEs rely primarily on personal savings of owners, business profits, family members or friends for their financial needs argued that (Okraku and Croffie 1997). They have little or no access to external credit. The effect of this is inadequate fixed capital as well as working capital. The consequences of these are very slow growth rate and frequent failures among small businesses. At the regulation level, the problems identified are high interest rates charged by banks thus making bank borrowing very expensive.

Small enterprise owners cannot easily access finance to expand business and they are usually faced with problems of collateral, feasibility studies and the unexplained bank charges. This means that they cannot access finance to enable them to grow. Ngobo (1995) makes a detailed analysis of finance as a constraining factor and includes collateral, interest rates, extra bank charges, inability to evaluate financial proposals and lack of financial management skills as hindrances to small enterprise growth. Under developed financial markets impose additional constraints. There are no financial instruments and no independent financial sources that are market driven. Lack of access to credit/ finance is affects technology choice by limiting the number of alternatives that can be considered. Many SMEs may use inappropriate technology because it is the only one they can afford. In some cases, even where credit is available, the entrepreneur may lack freedom of choice because the lending conditions may force the purchase of heavy, immovable equipment that can serve as collateral for the loan. Credit constraints operate in variety of ways in Kenya where undeveloped capital market forces entrepreneurs to rely on selffinancing or borrowing from friends or relatives. Lack of access to long-term credit for small enterprises forces them to rely on high cost short term finance.

Professional experience has been cited as an important factor affecting many aspects of entrepreneurial firms. Experience takes many guises and breadth of experience is shown to be an important factor driving the performance of firms, with the number of previous jobs positively related to new firm performance (Lumpkin \& 
Marvel 2007). Thapa (2007) found a positive association between education and small business success. The likelihood of failure was also found to be associated with the owner/manager's work experience prior to business launch and education. Human capital is the most critical agent of SME performance. The recruitment of academically qualified employees is a necessary start for sustainable human capital development in all organizations. Human capacity has become a critical index of competition in the world of business to the extent that the development of such capacities through training has become top priority in designing the strategic plan of business organizations (Tim \& Brinkerhoff, 2008).

Management is therefore necessary to enable group or business goals to be accomplished through the functions of planning, staffing, directing, controlling activities, coordination and directing. Personal characteristics of the owner/manager were interpreted by Larson and Clute (1979) as lack of experience among small business managers who happen to be the owners leading to poor performance and consequently to business failure. Bamback and Lawyer (1979) also identified poor management as the root cause of many failings and poor performance of small business. Nzioka (1995) in the role of education in business performance notes that one of the things that hold back the development of small -business is the need for better management.

Good management means need for proper planning, control, organizing skills and proper staffing with qualified and competent employees. Harper (1984) observes that the poor growth of many enterprises of all sizes, suggest that the scarcity of competent managers is a more serious constraint on economic development. As the enterprise becomes larger, the more need for managers to plan, coordinate and control the activities of the enterprise.

According to Haber, Jeffry (2004) Bookkeeping is a set of rules for recording financial information in a financial accounting system in which every transaction changes, when it comes to bookkeeping there are different situations in which it is used including personal and business banking.

Bookkeeping is the first essential step of accounting which as a system provide a source of information to owners and managers of SMEs operating in any industry for use in the measurement of financial performance. The importance of financial performance measurement to any business entity cannot be over emphasized. In this sense, the accounting bases, concepts and principles adopted ought to capture the relevant accounting information to ensure reliability in its measurement. Cooley and Edwards, (1983) contend that reported profits reflect changes in wealth of business owners. This can explain why major economic decisions in business are centered on financial performance as measured by profitability.

\subsubsection{Research Gap}

As previously mentioned, SMEs are a significant component of developing country economy like Ethiopia and there is a lack of empirical evidence concerning their accounting practice and its effect in raising credit from financial institutes and making investments of SMEs. Therefore, this study is expected to fill the gap by identify the accounting practice of SMIS and its effect on accessing finance in case of Arba Minch town southern region.

\subsection{Research Methodology}

The research designs adopted in this research were descriptive research design. This type of research is commonly conducted to collect detail description of existing phenomena with the intent of employing data to justify current conditions and whenever possible to draw valid general conclusion from the facts discovered.

The research approaches adopted in this research were quantitative and quantitative research strategies or tools that are relevant to achieve the desired research outcome based on survey design with structured close-ended questionnaires.

In this study were used both primary and secondary sources of data. The sources of primary data consisted of owner managers and legal officers and the employees having access to the issue relevant to the research. The information was obtained through interviews and questionnaires. The secondary data was collected on financial conditions, performance and growth of SMEs, annual reports and strategic plan of Arba Minch town trade and industry office.

Stratified random sampling techniques were used. The samples were randomly selected from two sub-cities. The sample was stratified by firm size class and economic activity. The number of firms in each of these strata of the sample was adjusted to increase the accuracy of the survey across activities and size classes.

The sample sizes for each economic activity were selected to ensure sufficient representativeness across the three major activities: construction, manufacturing, trade, urban agricultures. The total populations for this study are 727 firms exist in two sub-city of the town among those 88 firms are used as a sample size.

Sample size calculation

$\mathrm{n}=727 / 1+727(0.1)^{\wedge} 2=87.9(88)$

Simple descriptive statistics were used in the analysis of data. Descriptive statistics such as mean, mode, standard deviation and frequency distribution were used to analyze the data. Data were coded and entered into the Statistical Package for Social Sciences (SPSS) for analysis. Data presentation will be done by the use of pie charts, bar graphs, percentages and frequency tables. 
Regression analysis was also used to determine the relationship between variables (the dependent Access to finance and independent variables accounting practice, collateral, Education, Age of the firm).

In this thesis, multiple regression models with various independent variables were used.

The regression analysis will be conducted to find out the following:

Depending on the theoretical model and the measurements of the variables, the empirical model that this study employs is given by:

$\mathrm{AF}=\beta 0+\beta 1 \mathrm{COL}+\beta 2 \mathrm{ACP}+\beta 3 \mathrm{AGE}+\beta 4 \mathrm{EDU}+\varepsilon$

Where;

$\mathrm{AF}=$ Access to finance

$\mathrm{ACP}=$ accounting practice

$\mathrm{COL}=$ Collateral

$\mathrm{EDU}=$ Education

$\mathrm{AGE}=$ Age of the firm

$\varepsilon=$ error term

$\beta=$ coefficient

\subsection{Results and discussion}

Descriptive and inferential statistics have been used to discuss the findings of the study. A total of 88 questionnaires were distributed across the various SME in Ariba Minch town, out of which the whole sample SMEs 36 were medium sized and 52 were small scaled SMEs 88 were completed and retrieved, representing $100 \%$ retrieval (response) rate.

1.6.1 Distribution of the SME's by the legal

\begin{tabular}{|c|c|c|}
\hline Types of business & Number of SMEs & Percent \\
\hline Service & 21 & 23.9 \\
\hline Manufacturing & 30 & 34.1 \\
\hline Construction & 23 & 26.1 \\
\hline Trade & 2 & 2.3 \\
\hline Urban agriculture & 12 & 13.6 \\
\hline Total & 88 & 100 \\
\hline
\end{tabular}

Source: Survey outcome and own computation 2018

The result revealed that service $23.9 \%$, manufacturing $34.1 \%$, construction $26.1 \%$, of the sample SME, trade 2.3 percent and urban agriculture 13.6 percent of sample SME. The implications of this most of SME were manufacturing business operator.

1.6.2 Age of the SME

\begin{tabular}{|l|c|c|}
\hline Age of SMEs & Number of SMEs & Percent \\
\hline 1 to 7 years & 33 & 37.5 \\
\hline 7 to 11 years & 34 & 38.6 \\
\hline More than 11 years & 21 & 23.9 \\
\hline
\end{tabular}

Source: Survey outcome and own computation 2018

The survey results have indicated that the years of establishment of the enterprises in the town ranged from seven to more than eleven years. This indicted that the distribution of enterprises were established seven to and more than 11 years ago relatively $38.6 \& 23.9 \%$ respectively.

\subsubsection{Source of Financing SME at Start-Up and Expansion of the Business}

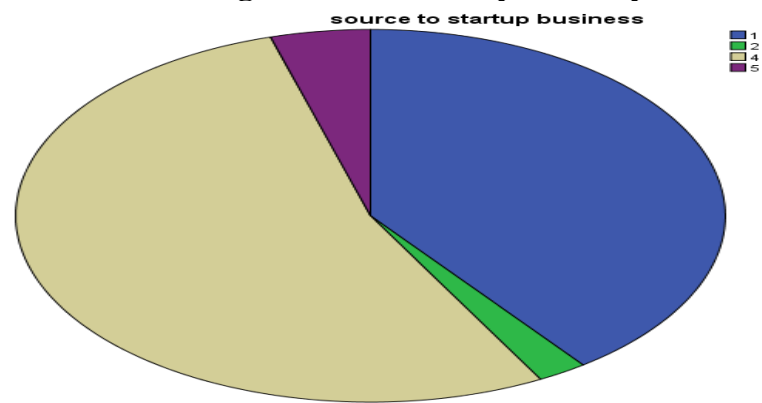

Source: Survey outcome and own computation 2018

Note: the numbers 1, 2, 3, 4 and 5 are indicates own saving, friend/ relatives, bank, microfinance, iqub respectively. The above figure displays an SME source of financing for the startup and expansion of the business. The study result shows that $39.8 \%$ of respondents started and expand business with their own money, 2.3\% SME started and expand business money obtained from relatives or friends, $53.48 \%$ of respondents started and expand 
business from microfinance institutions and $4.58 \%$ of respondents started and expand business from iqub schemes (social capital) claim. This indicates most of the SMEs access to the credit from financial institutions.

\subsubsection{Frequency of Accessing to Credit}

\begin{tabular}{|l|l|l|}
\hline Access to credit & Number of SMEs & Percent \\
\hline No access & 15 & 17.0 \\
\hline Only one time & 49 & 55.7 \\
\hline Only two time & 14 & 15.9 \\
\hline Only three time & 10 & 11.4 \\
\hline Total & 88 & 100 \\
\hline
\end{tabular}

Source: Survey outcome and own computation 2018

The above table the frequency of accessing to credit from sample SME having access to credit 17 percent of firm have no access to finance, 55.7 percent have one time access to credit, 15.9 percent have two time access to credit, and 11.4 percent of sampled SME have three time access to finance from micro finance institutions. Therefore the above result may indicates that there was a number of firms they cannot get access to credit, most of firms have only one time access to finance some only firms have two times access to finance and a few have three times access to credit from micro finance institutions.

The survey indicates that few SMEs get access to finance from banks.

\subsubsection{Regression result and Discussion}

\subsubsection{Access to finance regression result}

\begin{tabular}{|l|l|l|}
\hline & Access & Not access \\
\hline Access to finance & 64 & 24 \\
\hline \multicolumn{2}{|l|}{ Chi-square test $=18.182 \quad \mathrm{PV}=0.000^{* * *}$} \\
\hline
\end{tabular}

$* * * *$ indicates significance at $5 \%$ probability level

The above table indicate access to finance from financial institutions from 88 sampled SMEs 72 percent of the respondents have an access to finance and the remaining 28 percent have no access to finance.

Regression Models

\begin{tabular}{|c|c|c|c|c|c|c|c|c|c|}
\hline \multirow[t]{2}{*}{ Model } & \multirow[t]{2}{*}{$\mathrm{R}$} & \multirow{2}{*}{$\begin{array}{c}\mathrm{R} \\
\text { Square }\end{array}$} & \multirow{2}{*}{$\begin{array}{c}\text { Adjusted } \\
\text { R } \\
\text { Square }\end{array}$} & \multirow{2}{*}{$\begin{array}{l}\text { Std. Error of } \\
\text { the Estimate }\end{array}$} & \multicolumn{5}{|c|}{ Change Statistics } \\
\hline & & & & & $\begin{array}{l}\text { R Square } \\
\text { Change }\end{array}$ & F Change & df1 & $\mathrm{df} 2$ & Sig. F Change \\
\hline 1 & $.968^{\mathrm{a}}$ & .937 & .934 & .122 & .937 & 307.374 & 4 & 83 & .000 \\
\hline
\end{tabular}

The results from the table above designated that a combination access to credit and experience/ age of the business, academic back ground of SME manager, accounting record keeping, collateral had 93.4\% ( $\mathrm{R}$ square= 0.934) predictive likelihood of effect in Arba Minch SME firms to access finance from banks. The predicator variable explains $93.4 \%$ of the variation in access to credit measured by which was attributed to experience/ age of the business, academic back ground of SME manager, accounting record keeping, collateral. From the findings, $6.6 \%$ of the variance is unexplained. In the outcome, $\mathrm{R}$ shows the value of the multiple correlation coefficients between the dependent and the independent variable.Multiple $R=986-\mathrm{R}$ in the above table shows the correlation between dependent variable and independent variables. As given in the table, $R$ of 0986 represents a situation in which the model perfectly predicts the influencing factors of access to finance.

Analysis of Variance (ANOVA)

ANOVA $^{\mathrm{a}}$

\begin{tabular}{|ll|r|r|r|r|r|}
\hline Model & & Sum of Squares & Df & Mean Square & F & Sig. \\
\hline \multirow{2}{*}{1} & Regression & 18.214 & 4 & 4.553 & 2.374 & $.000^{\mathrm{b}}$ \\
& Residual & 1.230 & 83 & .015 & & \\
& Total & 19.443 & 87 & & & \\
\hline
\end{tabular}

Source own survey

a. Dependent Variable: access to credit

b. Predictors: (Constant), collateral, Experience of business, accounting record, academic background

The $\mathrm{P}$ value in the study is less than $5 \%$ level of significance as indicated by sign $<000$. Therefore, the study model significantly more variance in access to credit measured expected by chance. The study has established variables of experience/ age of the business, academic back ground of SME manager, accounting practice, collateral as factors that influence to access credit in Arba Minch. Significance of the study means that the regression model was also significant and therefore fit for the study. 
The Regression Coefficients of Model

The coefficients of the regression model are illustrated in the table below.

\begin{tabular}{|c|c|c|c|c|c|c|}
\hline \multirow{2}{*}{\multicolumn{2}{|c|}{ Model }} & \multicolumn{2}{|c|}{ Unstandardized Coefficients } & Standardized & \multirow[t]{2}{*}{$\mathrm{t}$} & \multirow[t]{2}{*}{ Sig. } \\
\hline & & $\mathrm{B}$ & Std. Error & Beta & & \\
\hline \multirow{5}{*}{1} & (Constant) & .005 & .060 & & .079 & .025 \\
\hline & Experience of business & -.015 & .027 & -.016 & -.547 & .007 \\
\hline & Academic background & .005 & .014 & .009 & .320 & .042 \\
\hline & Accounting record & .017 & .030 & .016 & .579 & .045 \\
\hline & Collateral & .984 & .028 & .967 & 34.559 & .000 \\
\hline
\end{tabular}

Source: Survey outcome and own computation 2018

The Regression Equation:

$\mathrm{AF}=\beta 0+\beta 1 \mathrm{COL}+\beta 2 \mathrm{ACP}+\beta 3 \mathrm{AGE}+\beta 4 \mathrm{EDU}+\varepsilon$

$\mathrm{AF}=0.05+0.984 \mathrm{COL}+0.017 \mathrm{ACP}-0.015 \mathrm{AGE}+0.005 \mathrm{EDU}+0.06$

The equation above inferred that financial performance access to credit was influenced to experience/ age of the business, academic back ground of SME manager, accounting record keeping, collateral. The regression coefficient for age/ experience of the business is -0.015 . This means that the relationship between access to credit and age/ experience of the business is negative. This implies that an access to credit is not affected by the age/ experience of the firm and vice versa.

The regression coefficient for academic back ground of SME manager is 0.005 . This means that the relationship between academic back ground of SME manager and access to credit is positive. This denotes that the academic back ground of the manager influences access to credit and vice versa.

The regression coefficient for accounting record keeping and access to finance is 0.017 . This means that the relationship between accounting record keeping and access to finance is positive. This indicates that effective accounting record keeping practice improve financial performance of SMEs and vice versa.

The regression coefficient for collateral is 0.984 . This means that the relationship between access to credit and collateral is strongly positive. This infers that collateral play a major role to access credit from bank for SMEs in Arba Minch.

\subsection{Conclusions and Recommendations}

\subsubsection{Conclusion}

SMEs have an important role for sustainable development, stable and equitable growth in any national economy. Ethiopia takes the development and expansion of SME's as the main way to solve many of the social problems. At present in Arba Minch town there are various reforms and development activities are being carried out. One of these is the promotion and development of SME's in the town and also given great attention in Growth and Transformation Plan (GTP 2) to alleviate urban unemployment problem by creating job opportunities for youth and so on.

SMEs lack access to institutional credit special they could not access bank credit because of lack of collateral; the study established that access to finance exposes businesses in to better opportunities to a great extent while it also leads to improved business performance to a great extent. The study also found out that access to finance for businesses is very challenging to a great extent. Overall, access to finance affects the performance of business causing them to encounter high financing costs and high failure rates. Similarly in Arba Minch town SMEs continue to exist with many problems among others are; inability to maintain accounting practice and lack of access to credit.

SMEs lack of access to credit is the result of accounting practice, collateral, age of the firm manager level of education, and accounting records, and the inefficient use of accounting information. Poor record keeping and accounting information make it difficult for financial institutions to evaluate potential risks and returns, making them unwilling to lend to SMEs. The misuse and inaccuracy of accounting information causes SMEs to inaccurately assess their financial situation, and make poor financial decisions, as well as leads them to face with the high failure rate. Ages of the firm and collateral are also the other determinant factor of the access to finance. All the above problems hinder SME not to continue to expand and function as expected in the country.

\subsubsection{Recommendations}

$>$ The study found out that most SMEs prefer to use personal savings, contributions from relatives and Iqub because they find it very difficult to access financing from banks due to strict requirements such as collateral security and high repayment costs. The study therefore recommends that banks and other credit giving financial institutions should come up with creative policies that make it easy for the SMEs to access financing.

$>$ Government should accelerate the development of market for financial services suited to the special 
characteristics of SMEs by promoting product innovation and building institutional capacity for developing capital of firms.

$>$ The government should start offering basic business and financial management skills as this will enable the SMEs to make informed investment decisions. This will enhance their entrepreneurial skills that will enable them to recognize and exploit the available business opportunities. And also the government needs to adopt Simplified financial reporting standards set for SME.

$>$ In collaboration with stakeholders the government should organize seminars and business drills for these SMEs. And other development partners like banks and saving and credit organizations should also educate these SMEs so that they may performer better.

\section{References}

- $\quad$ Byron, E.L. \&Friedlob, G.T. 1976, 1984, 'Why smallbusinesses fail', Management Accounting. .

- Daodu, O. (1997) "Promoting Entrepreneurship and Small Business: Lessons of Experience." In FadahunsiOlu and TunjiDaodu (edts) Small and Medium Enterprises

- Hopper, T. Koga, T. and Goto, J. (1999). Cost accounting in small and medium sized Japanese companies: an exploratory study. Accounting and Business Research 30(1),

- Hussein, M. E. (1983). Accounting and Control Systems for Small Businesses, ToucheRoss Foundation.

- Karunananda, A. \&Jayamaha A.(2011), Financial Practices and Performance of Small and Medium Sized Enterprises Srilanka

- $\quad$ Stigliz ,(1996). 'Economics of the public sector, W.W. NORTON and Co.Inc.'

- Wole, S. (2004). The Micro and Small Enterprises Sector in Ethiopia: An Over view. In W.Gebeyehu and D. Assefa. (eds.) The Role of Micro and Small Enterprises in the Economic Development of Ethiopia. Addis Ababa: FeMSEDA.

- $\quad$ Basu, A., Blavy, R. and Yulck, M. (2005) "Microfinance in Africa: Experience and Lessons from Selected African Countries " IMF Working Paper 04/1 7 4, Washington.

- Development: Policies, Programmes and Prospects. West African Management Development Institutes Network (W AMDEVN):

- Economic Perspective. (2004). MicroEnterpriseLayingtheoundationfor Economic Development.An Electronic Journal of the Us Department of State volume 9,number1

- Ekpenyong, D. B. (1992) 'Problems Of Small Business And Why They Fail.' Journal of General Studies, Bayero, University, Vol. 3, No.1 (1995) 'Financing Small Enterprising In Nigeria: Sources, Constraints And Prospect.

- Gebrehiwot, A and wolday, A. (2004). Micro and small enterprise development in EthiopiaSurvey Report. Addis Ababa

- Hailay, G. (2003). Entrepreneurship and Small Business Managment. Ethio-Central Printing Press.Mekelle

- Inang, E. E. and Ukpong, G. E. (1992) 'A Review of Small Scale Enterprises Credit Delivery Strategies in Nigeria.' CBN Economic and Financial Review, VoL 30.

- Mbroh, J.K \&Attom, B.E (2013), Accounting and Control Systems Practiced by Small and Micro Enterprise Owners within the Cape Coast Metropolitan Area of Ghana Asian journal of Business and Management Sciences Vol. 1

- Olatunji (2013). The Impact of Accounting System on the Performance of Small and Medium Scale Enterprises in Nigeria -A Survey of SME's in Oyo state -Nigeria Department of Management Accounting ladoke University of Technology. International Journal of Business and Management Invention vol. 21 